\title{
Efficiency of using Vitaferm in broiler poultry farming
}

\author{
Aleksei Reznichenko* \\ Belgorod State Agricultural University named after V. Y. Gorin, Mayskiy settlement, 308503, Belgorod region, Russia
}

\begin{abstract}
The cultivation of poultry without the use of antibacterial drugs is a vital direction of modern production, since the entry of domestic poultry products to the foreign market involves their absence in raw materials of animal origin. As experience confirms, enrichment of feed rations with enzyme preparations and vitamins reduces the waste of young animals, significantly increases the feed absorption, and reduces their feed-gain relations per production unit. This allows enhancing the productivity of poultry farming while simultaneously improving the quality of resulting products. We have studied the effect of the new vitamin-enzyme complex Vitaferm on the broiler-chickens body against the background of the antibacterial drugs exclusion from their antiepizootic measures. Studies have shown a positive effect of Vitaferm on the poultry body which is manifested by an increase in average daily growth, livability enlargement and reduced feed-gain relations per production unit. These changes can be explained by the normalization of the digestive system of broiler-chickens with the Vitaferm use. It is known that antibiotics inhibit the body's immune system and disturb the balance of intestinal microflora. Thus, the use of vitamin-enzyme complex Vitaferm with broiler-chicken feed at the rate of $15.0 \mathrm{~g} / \mathrm{kg}$, starting from the day-old up to 10 days, is proposed for the complete or partial exclusion of antibacterial drugs from the antiepizootic measures scheme.
\end{abstract}

\section{Introduction}

It is believed that the first 10 days of feeding are the most critical for broiler-chickens, since the formation of the gastrointestinal tract microflora and the body's immune system occurs during this period. The use of various antibiotics and other antibacterial drugs for chickens from the first days often leads to inhibition of the cilia development of the intestinal epithelium, disruption of the beneficial microflora formation in the digestive organs, dysbacteriosis, and necrotic enteritis. The above mentioned disorders reduce the growth of poultry and cause a waste of livestock $[1,2]$.

Therefore, an exogenous enzyme is an important component of poultry ration. It contributes to the improvement of the feed digestibility, environmental pollution decline, and the reduction of the production cost, which in turn leads to an increase in the livability and productivity of poultry $[3,4]$.

Feed enzymes increase livestock production efficiency. Many researchers believe that the need for meat will grow rapidly over the years. This is facilitated by a steady increase in population, especially in developing countries [5].

Enzymes of exogenous origin are able to convert feed polysaccharides from an insoluble form to a soluble one, allowing their nutrients to be more fully used by breaking down beta-glucans, cellulose, and pentosans. Moreover, these enzymes can destroy the cell walls of polysaccharides of vegetable feed leading to the release of previously inaccessible nutrients.
Therefore, supplementation of feed rations with enzyme preparations increases the level of feed digestibility reducing costs, since it becomes possible to partially replace expensive animal feeds with vegetable ones. It is also worth noting the fact that the use of exogenous enzymes lowers the waste of young animals and enhances the productivity of animals [6].

Ferments (enzymes) are specific proteins that act as biological catalysts in a living organism. Enzymes, unlike hormones and biostimulants, do not act on the bird's body but on feed components in the gastrointestinal tract. They do not accumulate in the body and livestock products [7].

Enzymes for the most part are very specific; they act selectively on certain substances (substrates) or groups of substances. Fermentolysis of starch and proteins is enhanced by the use of enzyme preparations containing mainly cellulase, pectinase, and hemicellulase. This is preceded by the cleavage of intermolecular bonds in the supramolecular complexes of fiber, that is, between cellulose, hemicellulose and pectin, as well as intramolecular bonds in these substances. This increases the availability of starch, protein and lipids for endogenous and exogenous hydrolases, and their digestibility. This sequence of changes in the digestion and metabolism processes of nutrients under the influence of enzyme preparations was established in experiments in vitro - during the feed incubation with enzymes in a different sequence, as well as on farm animals [8].

* Corresponding author: reznichenko6531@gmail.com 
The main reason for the enzymes use in animal husbandry is to reduce the feed cost because it equals to $70 \%$ of total costs. The use of exogenous enzymes in the ration formation allows achieving the required "flexibility" when it becomes possible to find a kind of compromise between the cost of basic raw materials and the resulting gains, as well as emissions into the environment.

It is known that cereals (rye, wheat, barley, and oat) are the main components of the poultry ration. They are in the lead of non-starchy polysaccharides content cellulose, pectin, part of beta-glucans, and pentosans and are indigestible. Their excess in monogastric animals feed prevents the access of digestive enzymes to nutrients, which accordingly worsens their use [9].

Non-starchy polysaccharides form a viscous solution enveloping the feed mass in the poultry's digestive tract. In this case, liquid sticky manure, in which the infection can spread rapidly, is formed. This leads to a significant decrease in poultry productivity, a decline in the feed energy value, and deterioration in its conversion.

Currently, many manufacturers offer ready-made feed with enzyme additives, most of which include enzymes that destroy non-starch polysaccharides of the grain cell wall - cellulase, hemicellulase, amylase [10]. The use of enzymes facilitates the feed base selection which allows working with any ration type. The enzymes application makes it possible to use cheaper ingredients in animal nutrition and obtain good results.

Vitamins are equally substantial in animal ration. It is believed that poultry are sensitive to a deficiency or complete lack of vitamins, which causes metabolic disorders. This leads to reduction in live weight gain, a decrease in productivity, and deterioration in the resulting product quality.

It should be noted that modern poultry farming is focused on reducing antibacterial drugs. In this regard, the employment of natural poultry growth stimulants for environmentally friendly products is especially vital. The stimulants are vitamins, enzymes, probiotics, prebiotics, and phytobiotics $[11,12]$.

Our developments are aimed at replacing antibacterial preparations in the ration of farm animals with other substances that are completely harmless to the human body.

The purpose of the experiment: To study the effect of the new vitamin-enzyme complex Vitaferm on the body of broiler-chickens to exclude or reduce the use of antibacterial preparations in poultry farming.

\section{Material and method of analysis}

Vitaferm is a loose powdery mass of light gray color with a specific smell. Its composition: pepsin - $1.5 \mathrm{mg}$, pancrease - $1.5 \mathrm{IU}$; vitamins, per 1g: A - $500 \mathrm{IU}$; E $0.74 \mathrm{mg}$; B1 - $0.17 \mathrm{mg}$; B2 - $0.17 \mathrm{mg}$; D3 - 44 IU; B6 $0.18 \mathrm{mg}$; RR - $2 \mathrm{mg}$; folic acid - $0.06 \mathrm{mg}$; pantothenic acid $-0.75 \mathrm{mg}$; biotin $-0.002 \mathrm{mg}$; B12 - $0.36 \mathrm{mcg}(\mu \mathrm{g})$; $\mathrm{C}-9.2 \mathrm{mg}$; citric acid $-20 \mathrm{mg}$; the rest is sucrose.

The formation of the control and experimental groups of poultry was carried out according to the principle of analogues.

The nature of the Vitaferm influence on the body of chickens was evaluated by clinical indicators, changes in protein, carbohydrate and mineral metabolism, growth intensity, and productivity.

Biochemical parameters were determined by conventional methods, herewith, a Hitachi hematology analyzer was used.

The digital material obtained in all the experiments was subjected to statistical processing on a personal computer using the conventional methods of variation statistics with the Student argument calculation (td). The difference between the compared values was considered significant at $\mathrm{p} \leq 0.05$ [13].

\section{Test results and discussion}

Five groups of day-old broilers with 50 units in each group were formed to conduct research on the basis of analogues. The first group was the control. Different doses of the vitamin-enzyme complex: 5.0, 10.0 and $15.0 \mathrm{~g} / \mathrm{kg}$ of feed, respectively, for 10 days were used in addition to the ration of the second, third and fourth experimental groups. The vitamin-enzyme complex with feed was also used for 10 days at the rate of $15.0 \mathrm{~g} / \mathrm{kg}$ to the fifth experimental group, but antibiotics were completely excluded from the scheme of antiepizootic measures.

Chickens in the control, second, third and fourth experimental groups received a ration using all antibacterial preparations according to the scheme adopted in the farm (cypromag was added to the water at the rate of $5 \mathrm{ml}$ per 101 for five days starting from twoday-old age, and this preparation with water was used from twenty-day-old age for five days).

Poultry observation was carried out until the age of 40 days.

The experimental scheme is presented in Table 1.

Table 1. Research scheme conducted on broiler-chickens

\begin{tabular}{|c|c|c|c|}
\hline Groups & $\begin{array}{c}\text { number of animal } \\
\text { units }\end{array}$ & Used preparations & $\begin{array}{c}\text { Dose, g/kg of } \\
\text { feed }\end{array}$ \\
\hline 1 - control & 50 & Basic ration (BR) & - \\
\hline 2 - experimental & 50 & BR+ Vitaferm & 5.0 \\
\hline $3-$ experimental & 50 & BR+ Vitaferm & 10.0 \\
\hline $4-$ experimental & 50 & BR+ Vitaferm & 15.0 \\
\hline 5 - experimental & 50 & $\begin{array}{c}\text { BR (without antibacterial } \\
\text { preparations) + Vitaferm }\end{array}$ & 15.0 \\
\hline
\end{tabular}


As a result of the studies, it was found that at the end of the experimental period, the average daily growths of the second, third and fourth experimental groups exceeded the control values by $2.5,3.5$ and $4.3 \%$, respectively. While in the fifth experimental group, where antibiotics were not used, the average daily gain of the poultry was $3.9 \%$ higher than the control.

Table 2. Vitaferm experiment results on broiler-chickens

\begin{tabular}{|c|c|c|c|c|c|}
\hline \multirow[b]{2}{*}{ Indicators } & \multicolumn{5}{|c|}{ Groups } \\
\hline & 1 - control & 2 - experimental & 3 - experimental & 4 - experimental & 5 - experimental \\
\hline $\begin{array}{l}\text { Number of animal units at the } \\
\text { beginning of the experiment }\end{array}$ & 50 & 50 & 50 & 50 & 50 \\
\hline at the end of the experiment & 49 & 49 & 49 & 50 & 50 \\
\hline Livability, $\%$ & 98 & 98 & 98 & 100 & 100 \\
\hline Average daily growth, $g$ & 64.9 & 66.5 & 67.2 & 67.7 & 67.4 \\
\hline $\begin{array}{l}\text { Feed-gain relation per } 1 \mathrm{~kg} \text { of growth, } \\
\mathrm{kg}\end{array}$ & 1.69 & 1.67 & 1.67 & 1.66 & 1.66 \\
\hline European index of productivity, un. & 382 & 396 & 400 & 414 & 412 \\
\hline
\end{tabular}

normalization of the digestive system of broiler-chickens

The death of chickens was noted in the control, second and third experimental groups during the entire research period.

The feed costs in all experimental groups were lower than the control indicators, and the productivity index was respectively higher.

Studies have shown a positive effect of Vitaferm on the poultry's body, which can be explained by the after using the preparation. It should be noted that the abolition of antibiotics against the background of the application of the vitamin-enzyme complex contributed to the poultry growth enlargement. It is evident that antibiotics inhibit the body's immune system, and upset the intestinal microflora balance.

The blood biochemical composition is presented in Table 3.

Table 3. Biochemical blood indicators of broiler-chickens $n=20(M \pm m)$

\begin{tabular}{|c|c|c|c|c|c|}
\hline \multirow{2}{*}{ Indicators } & \multicolumn{5}{|c|}{ Groups } \\
\cline { 2 - 6 } & $1-$ control & $2-$ experimental & $3-$ experimental & $4-$ experimental & $5-$ experimental \\
\hline Total protein, $g / L$ & $56.6 \pm 1.20$ & $57.9 \pm 1.43$ & $59.1 \pm 1.29$ & $59.7 \pm 1.21$ & $59.6 \pm 0.27$ \\
\hline Albumins, \% & $41.1 \pm 0.49$ & $42.1 \pm 0.86$ & $43.9 \pm 0.47^{* *}$ & $44.2 \pm 0.41^{* *}$ & $44.6 \pm 0.56^{* *}$ \\
\hline$\alpha-$ globulins, \% & $17.8 \pm 1.33$ & $17.6 \pm 1.65$ & $15.2 \pm 1.33$ & $15.6 \pm 1.61$ & $15.2 \pm 1.67$ \\
\hline$\beta$ - globulins, \% & $15.9 \pm 0.26$ & $16.2 \pm 0.77$ & $17.0 \pm 0.32^{*}$ & $16.9 \pm 0.24^{*}$ & $16.8 \pm 0.22^{*}$ \\
\hline$\gamma-$ globulins, \% & $25.2 \pm 0.67$ & $24.1 \pm 0.79$ & $23.9 \pm 0.79$ & $23.3 \pm 0.59$ & $24.1 \pm 0.60$ \\
\hline Calcium, $\mathrm{mmol} / \mathrm{L}$ & $3.59 \pm 0.65$ & $3.87 \pm 0.70$ & $4.88 \pm 0.40$ & $4.96 \pm 0.68$ & $4.53 \pm 0.62$ \\
\hline Phosphorus, $\mathrm{mmol} / \mathrm{L}$ & $2.47 \pm 0.21$ & $2.40 \pm 0.34$ & $2.23 \pm 0.32$ & $2.21 \pm 0.46$ & $2.24 \pm 0.32$ \\
\hline Cholesterol, $\mathrm{mmol} / \mathrm{L}$ & $1.49 \pm 0.33$ & $1.47 \pm 0.31$ & $1.44 \pm 0.39$ & $1.48 \pm 0.32$ & $1.52 \pm 0.37$ \\
\hline Glucose, $\mathrm{mmol} / \mathrm{L}$ & $16.3 \pm 0.62$ & $15.9 \pm 0.73$ & $16.9 \pm 0.69$ & $16.1 \pm 0.85$ & $16.2 \pm 0.79$ \\
\hline AST u/L & $232.2 \pm 7.28$ & $214.3 \pm 7.15$ & $200.7 \pm 6.77^{* *}$ & $199.3 \pm 8.39^{* *}$ & $194.8 \pm 7.59^{* *}$ \\
\hline ALT u/L & $62.8 \pm 3.67$ & $54.6 \pm 3.23$ & $57.0 \pm 3.24 *$ & $58.7 \pm 3.56^{*}$ & $58.9 \pm 3.88^{*}$ \\
\hline
\end{tabular}

Note: $-{ }^{*} \mathrm{p}<0.05$

It can be seen from the data presented in Table 3 that the total protein content in the blood serum of the chickens of the experimental groups was higher than the control values by $2.2-5.5 \%$ at the end of the experimental period. However, these changes did not have statistically significant differences.

The relative albumin content in the blood serum of chickens of the second experimental group slightly differed from the control values. Besides, it significantly increased in chickens of the third, fourth and fifth experimental groups by $6.8,7.5$ and $8.5 \%$, respectively, after applying the maximum doses of Vitaferm $(\mathrm{p}<0.01)$. This can be explained by the proteosynthesis activation in the liver.

The share of $\alpha$-globulins in the protein of chickens of the experimental groups did not statistically differ from the control, although it tended to decrease. Concerning $\beta$-globulins, their number increased by 6.9 and $6.3 \%$ in the third and fourth experimental groups, respectively, after applying the maximum doses of Vitaferm. Their level enhanced by $5.7 \%$ in the fifth experimental group, where antibiotics were excluded due to the use of the vitamin-enzyme complex. The difference with control was confirmed statistically in all cases $(p<0.05)$. It is known that complement components and immunoglobulins are comprised in the $\beta$-globulin fraction. Therefore, it can be assumed that Vitaferm promotes stimulation of the body's immune system.

It should be borne in mind that the level of $\gamma$ globulins in chickens of all experimental groups tended to decrease but the changes were not statistically different from the control. 
The level of calcium and phosphorus was determined by mineral elements. The content of these two elements in all experimental chickens corresponded to the physiological norm. Moreover, the content of total calcium tended to increase in the experimental groups, and inorganic phosphorus tended to decrease. However, these changes did not have a statistically significant difference with control.

The determination of serum cholesterol has the greatest clinical significance in the lipid metabolism assessment. In our studies, the cholesterol level in the chickens of the experimental groups did not have a statistically reliable difference with the control, which indicates the absence of the negative effect of the studied preparations on lipid metabolism.

A decline in the activity of aspartate aminotransferase by 15.7 and $16.5 \%$ was noted at the end of the experimental period in groups 3 and 4 , respectively, where the highest doses of Vitaferm were used. In the fifth experimental group, where antibiotics were not used, this indicator reduced by $19.2 \%$ compared with the control in all cases $\mathrm{p}<0.01$.

A decrease in the activity of alanine aminotransferase should also be noted in all experimental groups. However, these changes were not statistically confirmed with control.

Since the increased content of these enzymes in the blood serum was observed during the destruction of cardiomyocytes, liver diseases, skeletal muscle necrosis, then the functioning of these organs became normal after the application of the vitamin-enzyme complex. This, apparently, affected the growth of live weight gain of chickens.

When studying natural resistance (Table 4) in chickens of the third, fourth and fifth experimental groups, an increase in the phagocytic activity of pseudoeosinophils by 17.8, 15.9 and $21.5 \%$, and a growth in the bactericidal activity of blood serum by 17.2, 18.1 and $15.4 \%$, respectively, were found in comparison with the control.

Table 4. Indicators of natural resistance of broiler-chickens, $n=20(M \pm m)$

\begin{tabular}{|c|c|c|c|}
\hline \multirow{2}{*}{ Groups } & \multicolumn{3}{|c|}{ Indicators } \\
\cline { 2 - 4 } & Bactericidal activity, $\%$ & Phagocytic activity, \% & Lysozyme activity, \% \\
\hline 1 - control & $33.2 \pm 1.77$ & $37.7 \pm 1.66$ & $11.4 \pm 1.19$ \\
\hline 2- experimental & $31.8 \pm 1.63$ & $36.9 \pm 1.62$ & $10.6 \pm 1.18$ \\
\hline 3- experimental & $38.9 \pm 1.70^{*}$ & $44.4 \pm 1.82^{*}$ & $12.6 \pm 1.22$ \\
\hline 4- experimental & $39.2 \pm 1.64^{*}$ & $43.7 \pm 1.52^{*}$ & $13.8 \pm 0.55$ \\
\hline 5 - experimental & $38.3 \pm 1.81^{*}$ & $45.8 \pm 1.69^{*}$ & $12.6 \pm 1.21$ \\
\hline
\end{tabular}

$* \mathrm{p}<0.05$

\section{Conclusion}

The Vitaferm application to broiler-chickens has a positive effect on the biochemical blood composition of poultry, contributes to the increase in livability, productivity, and natural resistance. Moreover, the complete exclusion of antibacterial preparations from the poultry ration does not adversely affect the body.

\section{Practical proposals}

Vitaferm vitamin-enzyme complex is proposed for the partial exclusion of antibacterial preparations from the scheme of antiepizootic measures in broiler poultry farming. The preparation is recommended for use with feed in broiler chickens at the rate of $15.0 \mathrm{~g} / \mathrm{kg}$ starting from the day-old age for 10 days.

\section{References}

1. V.O. Ezhkov, Mater. of the Int. Sci. Conf. on the Pathophysiology of Animals (St. Petersburg, 2006) pp. 57-58

2. M.M. Goryacheva, Alternative to antibiotics, Poultry and poultry products, 1, 16-19 (2013)

3. S.B. Noskov, L.V. Reznichenko, Iu.A. Kharchenko, Achievem. of sci. and technol. of AIC, 2, 55-57 (2011)
4. L.N. Skvortsova, RAAS Reports, 3, 38-40 (2010)

5. A. Barletta, Current Market and Expected Developments, in: Enzymes in farm animal nutrition, 2rd ed. (2010) pp. 1-12

6. S.I. Kononenko, Proc. of Kuban State Agrar. Univer., 1(28), 107-108 (2011)

7. T.M. Okolelova, A.V. Kulakov, S.A. Moloskin, Vitamin and mineral nutrition of poultry (Moscow, 2000) 78 p.

8. T.M. Okolelova, N.V. Kulakova et al., Feed and enzymes (Sergiev Posad, 2001) 112 p.

9. L. Reznichenko, O. Bykova, F. Denisova, S. Vodyanitskaia, R. Shcherbinin, Int. J. of Advan. Bio-technol. and Res. (IJABR), 10(2), 560-566 (2019)

10. E.A. Kapitonova, N.V. Kozlova, Mater. of the XII Int. Sci. and Pract. Conf., dedicated to the $75^{\text {th }}$ anniver. of the Depart. of Pet Hygiene, Ecol., and Microbiol. of UO BSAA (Gorky; Zhodino, 2009) pp. 53-58

11. L.V. Reznichenko, S.B. Noskov, M.N. Penzeva, A.A. Manohin, Int. J. of Pharm. and Technol., 8(4), 26882-26888 (2016)

12. N. Yang, R.S. Jiang, World's Poultry Sci. J., 61, 373-381 (2005)

13. N.A. Plokhinskii, Biometrics (Moscow University Publ. House, Moscow, 1987) 367 p. 